\title{
Pleopod Cuticular Morphology \\ as an Index of Moult Stage \\ in the Ornate Rock Lobster, Panulirus ornatus (Fabricius 1789)
}

\section{T. Turnbull}

Division of Fisheries Research, CSIRO, P.O. Bungalow, Cairns, Qld 4870, Australia; Present address: Qld Dept Primary Industries, Northern Fisheries Research Centre, Box 5396, Cairns Mail Centre, Qld 4871, Australia.

\section{Abstract}

Seven discrete stages and substages of moulting in the ornate rock lobster, Panulirus ornatus, have been distinguished by microscopic examination of the cuticle and setae of the pleopods. The diagnostic features and the duration of each of the stages are described. Freezing did not visually alter the tissue features used to identify each moult stage. Pleopod morphology can reliably indicate whether a lobster has moulted within the previous $24 \mathrm{~h}$ or is within $72 \mathrm{~h}$ of the next ecdysis.

\section{Introduction}

The ornate rock lobster, Panulirus ornatus (Fabricius 1789), is widely distributed throughout the Indo-west Pacific (George 1968). In the Torres Strait and the Gulf of Papua, lobsters support diver fisheries that are an important source of income for the local people. The lobster is fast-growing, reaching maturity within about 3 years of hatching. From the Torres Strait, the adult lobsters migrate across the Gulf of Papua to breeding areas around Yule Island. The planktonic larvae are believed to be carried back to the Torres Strait and the east coast of Australia by prevailing currents (Moore and MacFarlane 1984).

Heavy fouling and old 'tar spots' (sperm packets) on the exoskeleton of lobsters caught at Yule Island, and the occasional recovery of external antennal tags (attached up to 6 months earlier in the Torres Strait), suggest that $P$. ornatus does not moult while migrating and breeding. Possibly, too, as R. Moore (personal communication) has suggested, populations of lobsters about to migrate moult synchronously.

To test these hypotheses it would be necessary to moult-stage large numbers of lobsters. Pleopod samples have been used to moult-stage large numbers of Panulirus marginatus (Lyle and McDonald 1983), but it was not known whether they were a reliable index for $P$. ornatus. Pleopods are readily available from the Torres Strait dive fishery, where only the tails of the speared lobsters are taken to the mother vessel or brought ashore.

Crustaceans are generally moult-staged by observing the degree of hardness of the exoskeleton and by examining, under a microscope, the transparent edge of the uropods or pleopods. Drach and Tchernigovtzeff (1967) distinguished five main stages in the moult cycle: A (immediate postmoult), B (postmoult), C (intermoult), D (premoult) and E (ecdysis); each had substages. This general scheme has been widely adopted and applied to a variety of crustaceans, including crayfish (Stevenson et al. 1968; Mills and Lake 1975; Peebles 1977; Van Herp and Bellon-Humbert 1978), lobsters (Aiken 1973; Dall and Barclay 1977; Lyle and MacDonald 1983) and prawns (Smith and Dall 1985).

Lyle and MacDonald (1983) reported a simple, accurate and rapid method of moultstaging lobsters in field populations of $P$. marginatus by examination of pleopod samples. 
They describe three stages: $A B, C$ and $D$. Stage $D$ is divided into six substages $\left(D_{0}, D_{1}^{\prime}\right.$, $\left.\mathrm{D}_{1}^{\prime \prime}, \mathrm{D}_{1}^{\prime \prime \prime}, \mathrm{D}_{2}, \mathrm{D}_{3-4}\right)$. These stages and substages are based solely on the cuticular morphology of the pleopods and follow the criteria established by Drach and Tchernigovtzeff (1967).

Initial examination of pleopod samples obtained from $P$. ornatus in the Torres Strait indicated that the developing setae at stage D differed in appearance from those of $P$. marginatus; this made identification of the moult stage uncertain. To provide a basis for using pleopods to moult-stage $P$. ornatus, a study was undertaken to provide a description of the changes in pleopod cuticular morphology occurring in $P$. ornatus during the moult cycle, determine the timing of the stages relative to ecdysis and determine whether pleopod samples could, as in P. marginatus (Lyle and MacDonald 1983), be frozen and thawed without altering the structure of the underlying soft tissue.

\section{Materials and Methods}

The study was carried out in Cairns, on the north-east coast of Australia. It was conducted in two parts: small lobsters, which moult frequently, were used to define the moult stages and then larger lobsters were used to confirm these stages and to time the stages relative to ecdysis.

\section{Small Lobsters}

During December 1984, five male and five female $P$. ornatus, ranging in size from 22 to $33 \mathrm{~mm}$ carapace length $(\mathrm{CL})$, were collected from the wharf piles in Trinity Inlet, Cairns. The lobsters were kept in individual cages in a $200-\mathrm{L}$ aquarium and fed daily on fish, squid and crustaceans. The temperature in the aquarium varied between 29 and $31^{\circ} \mathrm{C}$ during the study. At intervals over 31 days, pleopod samples were taken and the condition of the exoskeleton recorded. Lobsters that appeared to be in the intermoult stage were sampled every 4-5 days, whereas those in a pre- or postmoult condition were sampled daily where possible.

The distal half of a pleopod was removed with scissors, placed in water on a microscope slide and examined at $\times 100$ and $\times 400$ magnification. The moult stage and a description of the cuticular morphology were recorded for each sample. The slides were then labelled and frozen for later reference, at which time $\times 100$ and $\times 200$ micrographs were made of the samples. These micrographs were then compared with the original descriptions.

\section{Large Lobsters}

In September and October 1985, 54 lobsters ranging in size from 60 to $100 \mathrm{~mm} \mathrm{CL}$ were collected from Warrior Reef $\left(10^{\circ} \mathrm{S}, 143^{\circ} \mathrm{E}\right)$ in the Torres Strait. The lobsters were held in cages for up to 3 days, then airfreighted alive to the laboratory, where they were kept in groups of four to eight in five 300-L fibreglass aquaria. Each lobster was identified by means of an antennal tag. The laboratory conditions and pleopod sampling procedure were similar to those for the small lobsters. The water temperature in the aquaria varied between 25 and $29^{\circ} \mathrm{C}$, a range similar to that found on reefs in the Torres Strait. Individual lobsters were held for varying periods, depending on how many of their pleopod tips had been removed and at what stage they were in the moult cycle. A total of 15 lobsters moulted during the experiment. The distal half to one-third of a single pleopod was removed and examined fresh to determine the moult stage. The pleopod was then frozen, and re-examined later along with other samples. The re-examination was performed without reference to the original examination. Although successive samples from the same animal were usually taken from different pleopods, in some postmoult lobsters it was necessary to resample the same pleopod. Before a third examination, the pleopods were permanently mounted in hydromount.

\section{Results}

Moulting in $P$. ornatus can be divided into seven relatively discrete stages and substages that can be identified by setagenic events and epidermal retraction in the cuticle and epidermis of the pleopods. The stages are similar to those described for $P$. marginatus by Lyle and MacDonald (1983) and follow the criteria and nomenclature established by Drach and Tchernigovtzeff (1967). As the moult stages for large and small lobsters appeared to be 
the same, the following descriptions of each of the stages are derived from the examination of both groups. The diagnostic characteristics of each stage and substage, using only pleopod cuticular morphology, are described in Table 1. It was found that, to ensure consistency of staging, the section of the pleopod examined should be at least $10 \mathrm{~mm}$ long, without damaged or regenerating areas.

Table 1. Description of moult stages for Panulirus ornatus based on cuticular morphology

\begin{tabular}{ll}
\hline Stage & \multicolumn{1}{c}{ Diagnostic characteristics } \\
\hline $\mathrm{A}$ & setal walls thin and rough on the inside; poorly developed setal bases \\
$\mathrm{B}$ & partial thickening of setal walls; setal bases clearly visible; thin cuticle \\
$\mathrm{C}$ & thick setal walls; thick cuticle layer extending below the setal bases \\
$\mathrm{D}_{0}$ & retraction of epidermis from the cuticle \\
$\mathrm{D}_{1}^{\prime}$ & maximal retraction of the epidermis; first appearance of new setae in the retracted zone \\
$\mathrm{D}_{1}^{\prime \prime \prime}$ & new developing setae clearly visible \\
$\mathrm{D}_{2}$ & appearance of a new layer of cuticle \\
\hline
\end{tabular}
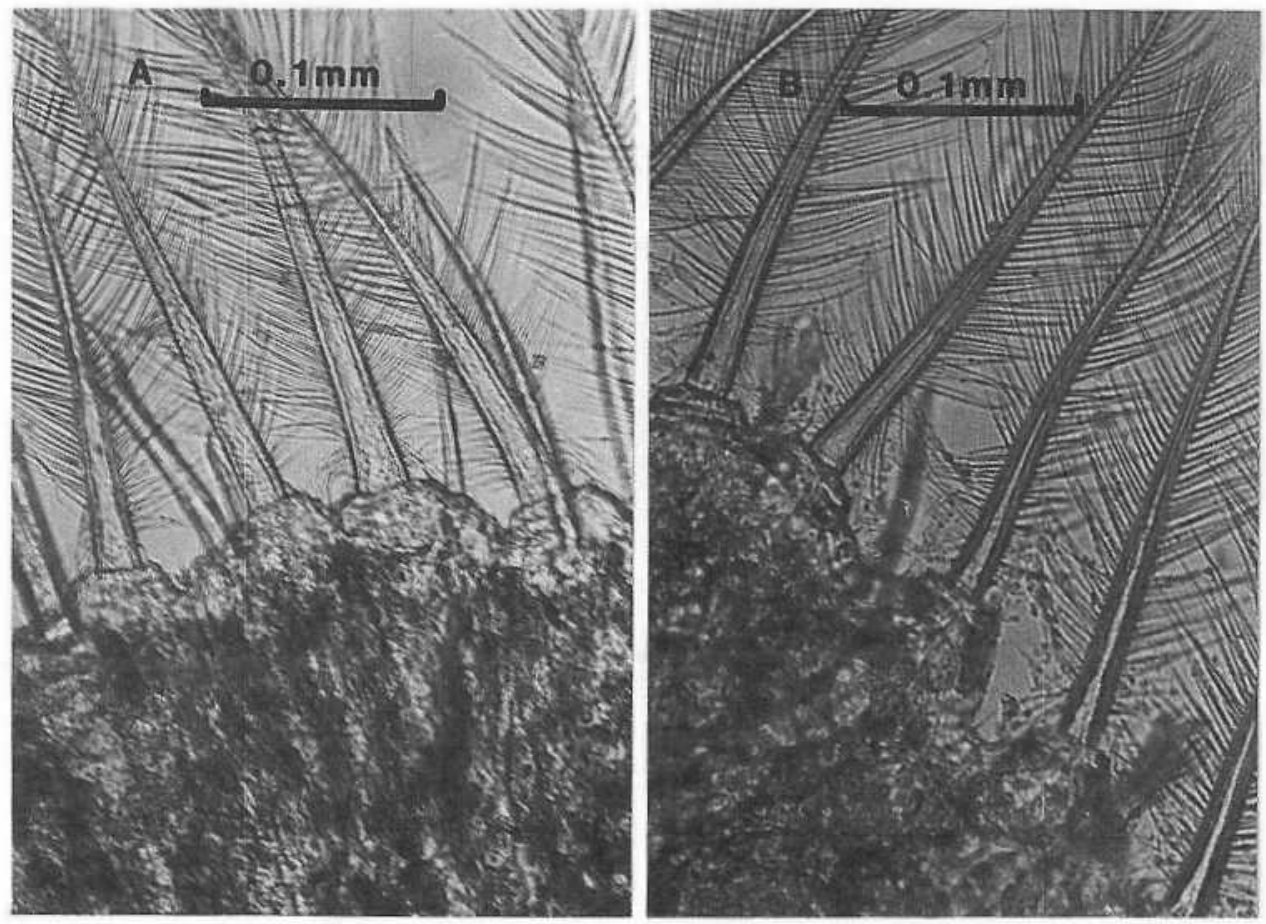

Fig. 1. Postmoult: $A$, stage $\mathrm{A} ; B$, stage $\mathrm{B}$.

\section{Postmoult}

Stage A: (Fig. 1A) The setal lumen is wide and granular. There is little or no thickening of the setal walls and the internal walls appear rough. The setal bases are poorly developed, with a very thin cuticle between them. The pigmentation in the epidermis extends up between the setal bases to the edge of the cuticle. During this stage the entire carapace is soft and parchment-like. 
Stage B: (Fig. $1 B$ ) The setal lumen generally appears less grainy. The setal walls have partially thickened, and the internal walls have a wavy, layered appearance. The setal bases are clearly visible, but the pigmentation in the epidermis still extends up to the setal bases. The cuticle between the setal bases is still thin and does not extend below them. At the beginning of this stage, only the spines and the top of the carapace are hard; the remainder of the carapace gradually hardens during this stage.

\section{Intermoult}

Stage C: (Fig. 2) The setal lumen is narrow and has lost most of its grainy appearance, and the setal walls are thick and smooth, particularly in the distal two-thirds. The cuticle is thick and is at least level with, and generally extends below, the setal bases. The pigmentation often appears to have retracted slightly from the setal bases (Fig. 2A). This apparent retraction can, at first glance, be mistaken for the commencement of apolysis. However, closer examination reveals a translucent, layered structure indicating cuticle (Fig. 2B). Late in this stage, the cuticle often forms a very thick layer beneath the setal bases.
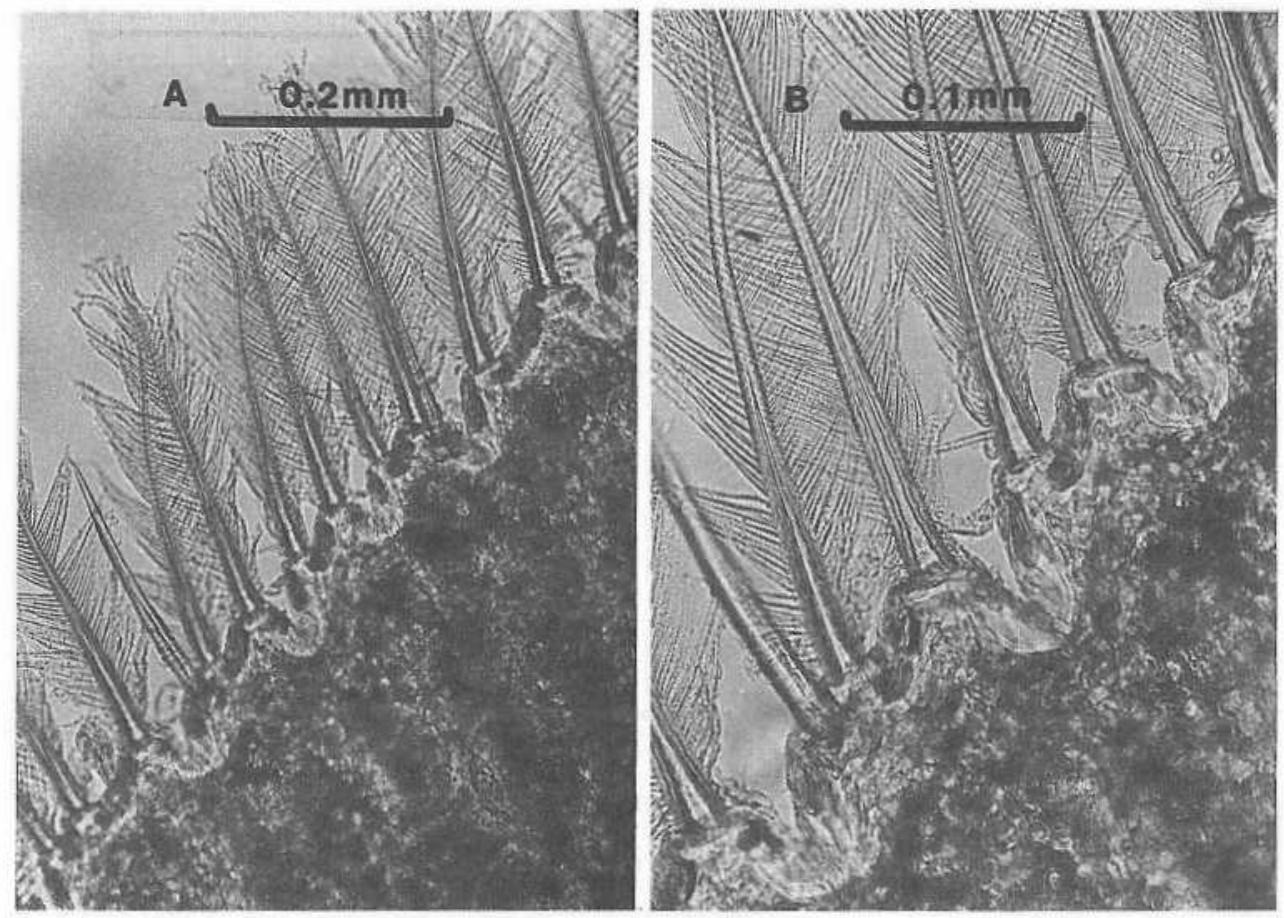

Fig. 2. Intermoult stage C: $A, \times 100 ; B, \times 200$.

\section{Premoult}

Stage $D_{0}$ : (Fig. $3 A$ ) The diagnostic feature of this stage is apolysis or retraction of the pigmented epidermis, which leaves a transparent gap between the cuticle and the epidermis.

Stage $D_{l}^{\prime}$ : (Fig. $3 B$ ) This stage is characterized by maximal retraction of the epidermis and the appearance of the distal half of the new setae as flaccid wisps of tissue in the retracted zone.

Stage $D_{1}^{\prime \prime \prime}$ : (Fig. $3 C$ ) The setae, complete with barbules, are clearly visible. The old cuticle and setae can be physically separated from the new by this stage. 




Fig. 3. Premoult: $A$, stage $\mathrm{D}_{0} ; B$, stage $\mathrm{D}_{1}^{\prime} ; C$, stage $\mathrm{D}_{1}^{\prime \prime \prime} ; D$, stage $\mathrm{D}_{2}$. 
Stage $D_{2}$ : (Fig. 3D) A transparent layer that corresponds to the new cuticle has formed above the epidermis. The new setae are thin-walled, amber-coloured and 'bushier' than in stage $\mathrm{D}_{1}^{\prime \prime \prime}$. In addition, the invaginations in the epidermis where new setae are developing are usually more pronounced than in stage $\mathrm{D}_{1}^{\prime \prime \prime}$. However, pigmentation hides most of the detail, so changes in the invaginations cannot be used as a criterion for subdividing the D stage, as has been done for other species (Stevenson et al. 1968; Mills and Lake 1975; Van Herp and Bellon-Humbert 1978; Smith and Dall 1985). No further visible changes occur in the pleopod tips until ecdysis. At the start of stage $D_{2}$, the carapace below the ecdysial line rapidly softens. No other macroscopic changes occur in the exoskeleton until ecdysis. The exuviae are hard, except for the area below the ecdysial line.

Table 2. Timing of pleopod moult stages in large ornate rock lobsters (carapace length 60-100 mm)

\begin{tabular}{|c|c|c|c|c|c|c|c|c|c|c|c|c|c|c|c|}
\hline \multirow{2}{*}{$\begin{array}{c}\text { Time } \\
\text { (days) }\end{array}$} & \multicolumn{15}{|c|}{ Lobster number } \\
\hline & 1 & 2 & 3 & 4 & 5 & 6 & 7 & 8 & 9 & 10 & 11 & 12 & 13 & 14 & 15 \\
\hline 12 & - & - & - & - & - & - & - & - & - & - & $\mathrm{D}_{0}$ & $\mathrm{C}$ & - & - & - \\
\hline 11 & - & - & - & - & - & - & $\mathrm{C}$ & - & - & - & - & - & - & - & - \\
\hline 10 & - & - & - & - & - & - & - & - & - & - & - & - & - & - & $\mathrm{D}_{0}$ \\
\hline 9 & - & - & - & - & - & - & - & - & - & $\mathrm{C}$ & - & - & $\mathrm{D}_{0}$ & - & $\mathrm{D}_{1}^{\prime}$ \\
\hline 8 & - & - & - & - & - & - & - & - & - & - & - & - & $\mathrm{D}_{0}$ & - & $D_{1}^{\prime}$ \\
\hline 7 & - & - & - & $\mathrm{D}_{0}$ & - & - & $\mathrm{D}_{0}$ & - & - & - & - & - & - & - & - \\
\hline 6 & - & - & - & - & - & - & - & - & - & - & - & - & $\mathrm{D}_{1}^{\prime}$ & $\mathrm{D}_{0}$ & - \\
\hline 5 & _- & - & $\mathrm{D}_{1}^{\prime \prime \prime}$ & - & - & - & - & - & - & - & - & - & $\mathrm{D}_{1}^{\prime \prime \prime}$ & $\mathbf{D}_{1}^{\prime \prime \prime}$ & - \\
\hline 4 & - & - & $\mathrm{D}_{1}^{\prime \prime \prime}$ & - & - & - & - & - & - & - & - & - & $\mathrm{D}_{1}^{\prime \prime \prime}$ & - & $\mathrm{D}_{1}^{\prime \prime}$ \\
\hline 3 & - & - & - & $\mathrm{D}_{2}$ & - & - & - & $\mathrm{D}_{2}$ & - & - & - & $\mathrm{D}_{2}$ & $\mathrm{D}_{2}$ & $\mathrm{D}_{2}$ & $\mathrm{D}_{1}^{\prime \prime}$ \\
\hline 2 & - & - & $\mathrm{D}_{2}$ & - & - & - & - & $\mathrm{D}_{2}$ & - & - & - & $\mathrm{D}_{2}$ & $\mathrm{D}_{2}$ & $\mathrm{D}_{2}$ & $\mathrm{D}_{2}$ \\
\hline 1 & - & - & - & - & - & - & - & $\mathrm{D}_{2}$ & $\mathrm{D}_{2}$ & $\mathrm{D}_{2}$ & $\mathrm{D}_{2}$ & $\mathrm{D}_{2}$ & $\mathrm{D}_{2}$ & $\mathrm{D}_{2}$ & $\mathrm{D}_{2}$ \\
\hline
\end{tabular}

Ecdysis

\begin{tabular}{llllllllllllllll}
1 & A & - & A & - & A & - & A & A & A & A & A & A & A & A & A \\
2 & - & - & B & B & - & - & B & - & B & B & B & B & B & B & B \\
3 & - & - & B & - & - & B & B & B & B & B & B & B & B & B & - \\
4 & - & C & - & C & - & - & C & B & - & C & B & B & - & B & - \\
5 & - & - & - & - & C & - & C & C & C & C & C & C & - & C & - \\
6 & C & - & - & - & - & C & C & - & - & C & C & - & - & - & - \\
\hline
\end{tabular}

\section{The Timing of the Stages Relative to Ecdysis}

The timing of the stages relative to ecdysis is summarized for large lobsters in Table 2 and for small lobsters in Table 3. Lobster number one has been omitted from Table 3 as it remained in stage $\mathrm{C}$ during the entire experiment.

In large lobsters, postmoult stage A occurs on day 1 post-ecdysis, and stage B on days 2-4 post-ecdysis (Table 2). Premoult starts between 12 and 6 days before ecdysis and only the timing of the last two stages has been well established. Stage $D_{2}$ begins 3 days before ecdysis, and stage $\mathrm{D}_{1}^{\prime \prime \prime}$ occurs between days 6 and 4 before ecdysis. In small lobsters, postmoult lasts 2 to 3 days and premoult begins 9 to 5 days before ecdysis (Table 3).

\section{Examination of Fresh, Frozen and Permanently Mounted Pleopods}

The morphology of pleopods microscopically examined before and after freezing did not change visibly and the moult stages assigned before freezing were consistent with those assigned after freezing $(n>100)$. Lyle and MacDonald (1983) have also concluded that freezing does not affect the accuracy of staging $P$. marginatus. Mounting the pleopods in 
hydromount did, however, produce a loss of detail, particularly in the $\mathrm{D}_{0}$ and in $\mathrm{D}_{1}^{\prime}$ stages. When specimens were preserved in hydromount, apolysis was difficult to observe in samples that had initially been identified as $D_{0}$, and the new setae could not been seen in samples that were $\mathrm{D}_{1}^{\prime}$. In a number of the $\mathrm{D}_{1}^{\prime \prime \prime}$ and $\mathrm{D}_{2}$ specimens, the retracted zone was squashed by the mounting procedure, which made the identification of the moult stage difficult.

Table 3. Timing of pleopod moult stages in small ornate rock lobsters (carapace length $22-33 \mathrm{~mm}$ )

\begin{tabular}{cccccccccc}
\hline $\begin{array}{c}\text { Time } \\
\text { (days) }\end{array}$ & 2 & 3 & 4 & 5 & 6 & 7 & 8 & 9 & 10 \\
\hline 11 & - & $\mathrm{C}$ & - & $\mathrm{C}$ & - & - & - & - & - \\
10 & - & - & $\mathrm{C}$ & - & - & $\mathrm{C}$ & - & - & - \\
9 & - & - & - & - & $\mathrm{D}_{0}$ & - & - & - & - \\
8 & - & - & - & - & - & - & - & - & - \\
7 & $\mathrm{D}_{0}$ & - & - & - & - & - & - & - & - \\
6 & $\mathrm{D}_{0}$ & - & - & - & - & - & - & $\mathrm{C}$ & - \\
5 & - & $\mathrm{D}_{1}^{\prime \prime}$ & - & - & - & - & - & - & $\mathrm{D}_{0}$ \\
4 & $\mathrm{D}_{1}^{\prime}$ & - & - & - & - & - & - & $\mathrm{D}_{1}^{\prime}$ & $\mathrm{D}_{0}$ \\
3 & - & $\mathrm{D}_{1}^{\prime \prime \prime}$ & - & $\mathrm{D}_{1}^{\prime \prime \prime}$ & - & $\mathrm{D}_{1}^{\prime \prime \prime}$ & - & - & $\mathrm{D}_{1}^{\prime \prime \prime}$ \\
2 & $\mathrm{D}_{1}^{\prime \prime \prime}$ & $\mathrm{D}_{2}$ & $\mathrm{D}_{1}^{\prime \prime \prime}$ & $\mathrm{D}_{2}$ & - & - & $\mathrm{D}_{2}$ & $\mathrm{D}_{1}^{\prime \prime \prime}$ & $\mathrm{D}_{2}$ \\
1 & $\mathrm{D}_{2}$ & - & $\mathrm{D}_{2}$ & $\mathrm{D}_{2}$ & - & $\mathrm{D}_{2}$ & $\mathrm{D}_{2}$ & $\mathrm{D}_{2}$ & $\mathrm{D}_{2}$ \\
\hline & & & & Ecdysis & & & & \\
1 & $\mathrm{~A}$ & $\mathrm{~A}$ & $\mathrm{~A}$ & $\mathrm{~A}$ & $\mathrm{~A}$ & $\mathrm{~B}$ & $\mathrm{~A}$ & - & $\mathrm{A}$ \\
2 & - & - & $\mathrm{B}$ & $\mathrm{B}$ & $\mathrm{B}$ & $\mathrm{B}$ & - & - & - \\
3 & - & - & $\mathrm{B}$ & - & $\mathrm{B}$ & $\mathrm{C}$ & $\mathrm{B}$ & $\mathrm{C}$ & - \\
4 & - & $\mathrm{C}$ & - & - & - & - & $\mathrm{C}$ & - & - \\
\hline
\end{tabular}

\section{Discussion}

The moult stages described for $P$. ornatus are similar to those given for $P$. marginatus by Lyle and MacDonald (1983). However, there are several differences. The AB stage of $P$. marginatus can be distinguished as separate stages in $P$. ornatus. The $\mathrm{D}_{1}^{\prime}$ and $\mathrm{D}_{1}^{\prime \prime}$ substages described in $P$. marginatus have been grouped into one substage $\left(\mathrm{D}_{1}^{\prime}\right)$, since, in $P$. ornatus, the appearance of new setae occurs at about the same time as maximal retraction of the epidermis. New setae formation in other decapod species occurs as early as substages $\mathrm{D}_{0}$ and $\mathrm{D}_{1}^{\prime}$ (Stevenson et al. 1968; Mills and Lake 1975; Van Herp and BellonHumbert 1978; Smith and Dall 1985). No substage between $\mathrm{D}_{1}^{\prime}$ and $\mathrm{D}_{1}^{\prime \prime \prime}$ could be easily distinguished in $P$. ornatus, as there was a rapid transition from the first appearance of setae as wispy structures to a stage that fits the $\mathrm{D}_{1}^{\prime \prime \prime}$ description.

In $P$. ornatus and Orconectes samborni (Stevenson et al. 1968), barbules were clearly visible on the developing setae in stage $\mathrm{D}_{1}^{\prime \prime \prime}$. This contrasts with $P$. marginatus, where barbules do not become visible until stage $\mathrm{D}_{2}$. In addition the old cuticle and setae can be removed by stage $\mathrm{D}_{1}^{\prime \prime \prime}$, whereas this does not occur until stage $\mathrm{D}_{3-4}$ in $P$. marginatus.

The features used to identify stage $\mathrm{D}_{3-4}$ in $P$. marginatus were not observed in $P$. ornatus, even in lobsters that were sampled within hours of ecdysis. Once the pleopods had taken on a $D_{2}$ appearance, there was no further visible change until ecdysis. This suggests that the $D_{3}$ and $D_{4}$ stages cannot be identified from pleopod cuticular morphology. Softening of the exoskeleton of $P$. ornatus below the ecdysial line, indicating the start of stage $D_{3}$ (Drach and Tchernigovtzeff 1967), occurs 3 days before ecdysis. At the same time a new layer of cuticle, which is the criterion for stage $D_{2}$, also becomes obvious. This suggests that, in $P$. ornatus, when the pleopod morphology clearly indicates a $\mathrm{D}_{2}$ stage, the animal has in fact reached the $\mathrm{D}_{3}$ stage of resorption of the exoskeleton. 
In large lobsters the stages immediately following ecdysis are brief: stage A lasts only 1 day after ecdysis and stage B between 2 and 4 days after ecdysis. The latter could be a slight under-estimate, as distinguishing a late-stage B from an early-stage $\mathrm{C}$ is difficult and somewhat subjective. Doubtful cases were classed as C. Travis (1954) found that stages A and B occupied a period of 5-6 days after ecdysis in P. argus.

The length of stage $\mathrm{C}$ is variable and likely to be affected by intrinsic factors such as size, age, physical condition (Aiken 1973, 1980; Chittleborough 1975), migratory or sexual behaviour (Moore, personal communication) and extrinsic factors such as temperature and availability of food (Travis 1954; Chittleborough 1975).

Stage $\mathrm{D}_{0}$ also appears to be variable, but occurs at least 6 days before ecdysis in large lobsters. Aiken (1980) reports a $\mathrm{D}_{2}$ 'plateau' in $H$. americanus that can vary in length from a few days to several months, with further variation between pleopods at the $C_{3}-D_{0}$ transition in an individual lobster. Substage $\mathrm{D}_{1}^{\prime \prime \prime}$ generally occurs 3-6 days before ecdysis and $\mathrm{D}_{2}$ starts 3 days before ecdysis.

In smaller lobsters, the stages last for a shorter time (Table 3). This is as expected, as smaller size and higher water temperature usually decrease the interval between moults in other lobsters (Chittleborough 1975; Aiken 1980).

Any qualitative description of pleopod morphology necessarily involves subjectivity. Nonetheless, the microscopic examination of the cuticle and setae of pleopods from $P$. ornatus provides a relatively rapid and reliable index of the moult stage of the lobster. The easily identifiable stage $A$ and substage $D_{2}$ give an accuracy of to within 1 day after ecdysis and 3 days before ecdysis. Since freezing does not alter pleopod morphology, representative samples of $P$. ornatus pleopods may be examined in the laboratory to moultstage commercially caught lobsters from the Torres Strait Fishery.

\section{Acknowledgments}

I wish to acknowledge the assistance of Stewart Bell, Lyle Squire and Jasper Trendall with the field and laboratory work, and especially thank Jasper Trendall for his constructive reviews of the original drafts of the manuscript. Chris Chubb and David Smith provided additional references and helpful criticism of the manuscript. I thank the Northern Fisheries Research Centre (Qld D.P.I. Fisheries Research Branch) for the use of their aquarium facilities. This work was carried out by the Tropical Rock Lobster Project of the CSIRO Division of Fisheries Research. The funding for the project was provided by the Department of Primary Industry and Energy, Australian Fisheries Service.

\section{References}

Aiken, D. A. (1973). Proecdysis, setal development, and molt prediction in the American lobster (Homarus americanus). Journal of Fisheries Research Board of Canada 30, 1337-44.

Aiken, D. A. (1980). Moulting and growth. In 'The Biology and Management of Lobsters Vol. 1'. (Eds J. S. Cobb and B. F. Phillips.) pp. 91-163. (Academic Press: New York.)

Chittleborough, R. G. (1975). Environmental factors affecting growth and survival of juvenile western rock lobsters Panulirus longipes (Milne-Edwards). Australian Journal of Marine and Freshwater Research 26, 177-96.

Dall, W., and Barclay, M. C. (1977). Induction of viable ecdysis in the western rock lobster by 20-hydroxyecdysone. General and Comparative Endocrinology 31, 323-34.

Drach, P., and Tchernigovtzeff, C. (1967). Sur la méthode de détermination des stades d'intermue et son application général aux Crustaces. Vie et Milieu (A) 18, 597-607.

George, R. W. (1968). Tropical spiny lobsters, Panulirus spp., of western Australia (and the IndoWest Pacific). Journal of the Royal Society of Western Australia 51, 33-8.

Lyle, W. G., and MacDonald, C. D. (1983). Molt stage determination in the Hawaiian spiny lobster Panulirus marginatus. Journal of Crustacean Biology 3(2), 208-16.

Mills, B. J., and Lake, P. S. (1975). Setal development and moult staging in the crayfish, Parastacoides tasmanicus (Erichson), (Decapoda Parastacidae). Australian Journal of Marine and Freshwater Research 26, 103-7. 
Moore, R., and MacFarlane, J. W. (1984). Migration of the ornate rock lobster, Panulirus ornatus (Fabricius), in Papua New Guinea. Australian Journal of Marine Freshwater Research 35, $197-212$. Peebles, J. (1977). A rapid technique for moult staging in live Macrobrachium rosenbergii. Aquaculture 12, $173-80$.

Smith, D. M., and Dall, W. (1985). Moult staging the tiger prawn Penaeus esculentus. In 'Second Australian National Prawn Seminar'. (Eds P. C. Rothlisberg, B. J. Hill and D. J. Staples.) pp. 88593. (NPS2: Cleveland, Australia.)

Stevenson, J. R., Guckert, R. H., and Cohen, J. D. (1968). Lack of correlation of some proecdysial growth and development processes in the crayfish. Biological Bulletin (Woods Hole) 134, 160-75.

Travis, D. F. (1954). The molting cycle of the spiny Iobster, Panulirus argus Latreille. I. Moulting and growth in laboratory-maintained individuals. Biological Bulletin (Woods Hole) 107, 433-50.

Van Herp, F., and Bellon-Humbert, C. (1978). Setal development and molt prediction in the larvae and adults of the crayfish, Astacus leptodactylus (Nordmann, 1842). Aquaculture 14, 189-301.

Manuscript received 4 October 1988, revised 7 February 1989, accepted 14 March 1989 